\title{
Os Atores da Construção da Categoria Agricultura Familiar no Brasil
}

\author{
Everton Lazzaretti Picolotto ${ }^{1}$
}

Resumo: O artigo tem por objetivo refletir sobre o processo de construção da categoria agricultura familiar no Brasil contemporâneo. A reflexão aqui sintetizada toma por base a revisita aos principais trabalhos acadêmicos que contribuíram para definir o campo de reflexão da agricultura familiar no Brasil, análise documental e entrevistas com lideranças e assessores do sindicalismo da agricultura familiar. Argumenta-se que existiram três conjuntos de atores que promoveram a construção da categoria agricultura familiar no Brasil: alguns trabalhos acadêmicos que deram base para repensar o lugar teórico desta agricultura na história e no desenvolvimento do país; as políticas do Estado e as normativas legais que deram visibilidade e definiram operacionalmente como se compreende esta categoria; e as organizações de agricultores familiares que têm identificado nesta categoria o seu projeto de agricultura e a utilizam como identidade política.

Palavras-chaves: agricultura familiar, sindicalismo, ações do Estado, debate acadêmico, reconhecimento.

Abstract: The present paper aims at a reflection on the process of building the family farm category in contemporary Brazil. The reflection synthesized here is based on revisiting the main academic papers which have contributed to define the field of reflection of family farming in Brazil, documentary analysis and interviews with leaders and advisors of unionism family farming. It is argued that there were three sets of actors who promoted the construction of the category family farming in Brazil: some academic work that provided the basis for rethinking the theoretical location of this farm in the history and development of the country; State policies and legal regulations that gave visibility and operationally defined as comprising this category, and organizations of family farmers who have identified this category as their project and the use of agriculture as a political identity.

Key-words: family farming, unionism, State actions, academic debate, recognition.

Classificação JEL: Q19.

1. Doutor em Ciências Sociais pela Universidade Federal Rural do Rio de Janeiro (UFRRJ), Professor Adjunto do Departamento de Ciências Sociais e do Programa de Pós-graduação em Ciências Sociais da Universidade Federal de Santa Maria (UFSM), RS, Brasil. E-mail: everton.picolotto@ufsm.br 


\section{Introdução}

A emergência da categoria agricultura familiar e dos agricultores familiares como personagens políticos é recente na história brasileira. Especialmente nas duas últimas décadas, vem ocorrendo um processo complexo de construção da categoria agricultura familiar, enquanto modelo de agricultura e como identidade política de grupos de agricultores. Para isso, contribuíram um conjunto de atores que, cada um ,segundo sua forma e segundo seus interesses, ajudou a definir o que se entende por agricultura familiar no país.

Argumenta-se, neste artigo, que foram três conjuntos de atores construtores e difusores da categoria a agricultura familiar e dos seus sujeitos políticos: os agricultores familiares. Este processo teve início em meados da década de 1980 e alcançou seus resultados mais expressivos de proposição e divulgação a partir da década de 1990. O primeiro foi composto pelo debate acadêmico que recolocou luz sobre o lugar que a agricultura familiar ocupou no desenvolvimento dos países do capitalismo avançado e as condições de precariedade que ela encontrou historicamente no Brasil. O segundo é representado pelas ações do Estado que contribuíram para definir o sentido oficial da categoria agricultura familiar e as políticas públicas que a fortaleceram. O terceiro, nem por isso menos importante, é composto pelo sin- dicalismo dos trabalhadores rurais (que passa a ser mais identificado coma agricultura familiar) e pelos movimentos sociais do campo que, mesmo sendo formado por forças políticas diversas, conseguiram organizar projetos de um novo lugar para a agricultura familiar no país.

O reconhecimento da agricultura familiar no país tem se dado de três formas principais, distintas, mas complementares entre si. A primeira diz respeito ao aumento de sua importância política e dos atores que se constituíram como seus representantes (com a formação da Federação dos Trabalhadores na Agricultura Familiar (Fetraf) como organização específica de agricultores familiares e, de outro lado, com a reorientação política da Confederação Nacional dos Trabalhadores na Agricultura (Contag), que a partir de meados dos anos 1990, passou a fazer uso da categoria agricultor familiar). A segunda se refere ao reconhecimento institucional propiciado pela definição de espaços no Estado, criação de políticas públicas e pela Lei da Agricultura Familiar. E a terceira advém do trabalho de reversão das valorações negativas que eram atribuídas a este modelo de agricultura, tais como: atrasada, ineficiente e inadequada. Por meio de uma luta simbólica movida pelo sindicalismo, por setores acadêmicos e do Estado, a agricultura familiar passou a ser associada com adjetivos considerados positivos, tais como: moderna, eficiente, sustentável, solidária e produtora de alimentos. Tais reversões de valores estão 
intimamente vinculadas ao processo de construção da agricultura familiar enquanto modelo de agricultura do tempo presente e do agricultor familiar como personagem político.

O reconhecimento, neste caso, não deve ser entendido como uma mera consideração formal da categoria, pautada em leis e políticas públicas, mas como um processo complexo de construção de grupos ou categorias sociais rurais inferiorizadas historicamente e em luta por fazer-se reconhecer frente a outros atores e perante o Estado. Nesta perspectiva, juntamente com a afirmação política de um grupo social, por meio da afirmação de seus atores políticos de representação e do reconhecimento destes pelo Estado e por outros atores, deve-se dar também a devida atenção à "gramática moral dos conflitos sociais" (HONNETH, 2009), pois, além das situações de carências materiais e políticas que podem motivar ações coletivas, também existem as situações de "injustiça" e "desrespeito social" que, quando percebidas intersubjetivamente como típicos de um grupo inteiro, podem se tornar base motivacional para resistências ou para ações que buscam a reversão de condição de inferioridade social.

Considerando-se as produções destes conjuntos de atores e o reconhecimento que alcançaram, argumenta-se que a definição atual da categoria agricultura familiar é resultado de um trabalho de construção política e de sentidos realizada nos embates travados em um "campo de forças" (BOURDIEU, 2005), em que atuaram atores diversos, como da academia, do Estado e de organizações que se propõem a ser representantes dos agricultores em geral, ou de uma parcela deles, ao mesmo tempo em que são construtores de modelos de exploração na agricultura e de visões de mundo. Neste sentido, os agricultores familiares e as suas organizações de representação não foram coadjuvantes neste processo, mas estiveram presentes na experiência histórica do seu próprio "fazer-se" (THOMPSON, 1987) enquanto personagens políticos do Brasil contemporâneo.

Este trabalho tem por objetivo refletir sobre os atores e o processo de construção da categoria agricultura familiar no Brasil contemporâneo.
Os investimentos de pesquisa aqui sistematizados tiveram por base a revisita aos principais trabalhos acadêmicos que contribuíram para definir o campo de reflexão da agricultura familiar no Brasil, a análise documental e entrevistas com lideranças e assessores do sindicalismo da agricultura familiar e dos trabalhadores rurais. A reflexão deriva da tese de doutorado do autor (PICOLOTTO, 2011).

\section{Agricultura de base familiar na história brasileira: um setor subsidiário à grande exploração}

A agricultura de base familiar na história brasileira, quando pensada do ponto de vista da sua importância socioeconômica, foi relegada pelo Estado e pelos setores dominantes a uma condição subsidiária aos interesses da grande exploração agropecuária. Esta última foi considerada, ao longo do tempo, como a única capaz de garantir divisas para o país através da exportação de produtos agrícolas de interesse internacional. Nas regiões estratégicas para a exploração de produtos de exportação, coube à exploração familiar funções consideradas secundárias, tais como: a produção de alimentos para o mercado interno (principalmente para as populações das cidades) e servir como reserva de força de trabalho acessória nos momentos em que as grandes explorações necessitassem.

A invisibilidade socioeconômica e política da agricultura de base familiar foi fruto de um longo processo de subjugação e, em muitos casos, de dependência da grande agricultura de exportação. A grande propriedade, dominante em toda a história brasileira, se impôs como modelo socialmente reconhecido. Como têm apontado alguns trabalhos historiográficos, à margem ou associada à grande exploração agropecuária, sempre existiu uma grande diversidade de formas sociais e de trabalho: "Esses fundamentais agentes camponeses agricultores apareciam sob a designação de colonos, arrendatários, parceiros, 
agregados, moradores e até sitiantes, termos que não podem ser compreendidos sem a articulação com a grande produção agroindustrial e pastoril" (MOTTA e ZARTH, 2008, p. 9-10). Da mesma forma, "ao lado de donatários e sesmeiros, apareciam os foreiros, os posseiros, os intrusos ou invasores, os posseiros criminosos etc." (MOTTA e ZARTH, 2008, p. 9-10).

Por outro lado, há que se considerar também que o Estado atuou na formação de pequenas propriedades em alguns momentos históricos e locais específicos objetivando ocupar áreas pouco povoadas consideradas estratégicas, tais como a colonização com imigrantes europeus no século XIX e no início do século XX em regiões de matas dos três estados do Sul; os projetos de colonização do governo de Getúlio Vargas nos anos de 1930-50 por meio de deslocamentos populacionais do Nordeste e do Sul para os estados do Paraná, Goiás e Mato Grosso do Sul; os projetos de colonização dos governos militares com deslocamentos populacionais de regiões com tensões sociais para o Mato Grosso, Rondônia e Pará nas décadas de 1960-70; entre outros (TAVARES DOS SANTOS, 1993; MEDEIROS, 1995).

A condição de menor importância e de invisibilidade social da agricultura de base familiar foi discutida por Maria Isaura Pereira de Queiroz no artigo Uma categoria rural esquecida (1963), publicado em um momento que o tema da reforma agrária estava sendo pautado no cenário nacional e eram apontadas como categorias opostas nos seus interesses os latifundiários e dos assalariados rurais. Com base em dados de Caio Prado Jre Jacques Lambert, Queiroz chama atenção para o fato de que naquele momento as grandes lavouras de exportação cobriam apenas 3,5 milhões de hectares $(27,2 \%$ da área brasileira), enquanto sobravam para as culturas de subsistência 14 milhões de hectares (mais de 70\%). Com base nesses dados e discordando da interpretação que Caio Prado Jr fazia deles, para quem a imensa maioria do território nacional não ocupada pelas grandes explorações seria "desabitada" (a "sobra"), Queiroz afirma que o Brasil "não é um país predominantemente monocultor, e sim um país de policulturas; a pequena roça de policultura fornece alimentação aos sessenta milhões de habitantes do Brasil e emprega a maioria dos homens do campo" (1963/2009, p. 61). Entretanto, a autora reconhece que esses agricultores (posseiros, pequenos proprietários ou agregados) existiam em situações de extrema precariedade no que se refere ao seu modo de vida rudimentar e miserável, à falta de ordenamento legal sobre as terras, à pouca relação com os mercados e à falta de acesso às técnicas modernas e ao crédito público. Era uma situação de extrema debilidade que se refletia na sua invisibilidade social e política.

Brumer et al. (1993, p. 180) dialogam com as observações de Queiroz e afirmam que a agricultura de base familiar "nasceu no Brasil sob o signo da precariedade, precariedade jurídica, econômica e social do controle dos meios de trabalho e de produção e, especialmente, da terra". Precariedade que se revestiu também no "caráter rudimentar dos sistemas de cultura e das técnicas de produção" e da sua pobreza generalizada.

Mesmo que as formas de precariedade tenham sido diferenciadas nas diversas regióes brasileiras, os agricultores de base familiar para continuarem persistindo precisaram, de uma maneira ou de outra, abrir caminho entre as dificuldades encontradas. Conforme Wanderley (1996),

\section{submeter-se à grande propriedade ou isolar-se em áreas mais distantes; depender exclusiva- mente dos insuficientes resultados do traba- lho no sítio ou completar a renda, trabalhando no eito de propriedades alheias; migrar tem- porária ou definitivamente. São igualmente fonte de precariedade: a instabilidade gerada pela alternância entre anos bons e secos no sertão nordestino; os efeitos do esgotamento do solo nas colônias do Sul (p. 9).}

Essa situação de precariedade, na maioria das vezes, limitou a constituição de uma categoria de agricultores centrados no trabalho familiar que pudesse fazer um contrapeso socioeconômico e político aos grandes proprietários e suas organizações. Nesse sentido, além dos agricultores de 
base familiar terem sido desprivilegiados no que concerne ao acesso à terra, ao crédito público e às técnicas modernas, também tiveram grandes dificuldades para construir forças políticas autônomas que pudessem desafiar os grandes proprietários e o modelo de agricultura dominante. Como afirma Gramsci (2002), as "classes ou grupos subalternos", pela sua condição de dominados política e culturalmente, têm grande dificuldade de se unificar e de construir instrumentos organizativos autônomos. As iniciativas de unificação desses grupos são continuamente desarticuladas pela ação dos grupos dominantes (que também dirigem o Estado) seja por instrumentos de repressão, seja pela desqualificação moral e cultural.

Estes elementos ajudam a compreender o porquê somente em meados do século XX foi possível a constituição de organizações de representação política autônomas dos grupos subalternos no campo; organizações que puderam superar o isolamento e os localismos. Com as ligas camponesas, o sindicalismo de trabalhadores rurais, o movimento dos agricultores sem terra, os sindicatos e cooperativas de colonos no Sul, entre outras formas de organização política (MEDEIROS, 1989, 1995, 2001; NOVAES, 1997; HELLER DA SILVA, 2006; PICOLOTTO, 2011).

\section{Emergência da categoria agricultura familiar: possibilidades de novo lugar teórico para os subalternos do campo}

Alguns estudos acadêmicos e outros elaborados por órgãos de Estado e organizações internacionais tiveram papel relevante na afirmação da categoria agricultura familiar no país nas últimas décadas. Primeiramente, cabe salientar que a emergência da noção de agricultura familiar não apenas substituiu o termo pequena pro$d u c ̧ a \tilde{o}$ por outro equivalente, mas promoveu um deslocamento teórico e de sentido sobre o que representa este segmento de agricultores. Tal deslocamento pode ser percebido claramente na diferença do enfoque que os trabalhos acadêmicos realizados nas décadas de 1970 e 1980 davam para a pequena produção, centrados que estiveram na investigação sobre o caráter capitalista da sua agricultura, sobre o que tinham de tradicional e de moderno, sobre processos de integração/subordinação frente à indústria. No geral, os trabalhos tomavam um enfoque teórico negativo sobre a pequena produção (inspirados em concepções marxistas, em especial em Lênin e Kautsky), vindo a identificar que estava em vias de desaparecimento com o avançar das relações capitalistas no campo. Wanderley (2009) relata os termos do debate da época: "Os olhares convergiam, em grande parte, para a constituição, no setor agrícola, de uma estrutura empresarial e para a emergência de um proletariado gerado por um mercado de trabalho específico ou unificado" (p. 185).

Dessa época, há que se registrar a relevante contribuição (que foge a regra) e a antecipação de questões de debate posterior levantadas pelo trabalho realizado por uma equipe de pesquisadores $^{2}$ coordenada por José Graziano da Silva sobre a Estrutura agrária e produção de subsistência na agricultura brasileira (1978). Este trabalho, realizado a pedido da Confederação Nacional dos Trabalhadores na Agricultura (Contag) com base no cadastro de imóveis do Instituto Nacional de Colonização e Reforma Agrária (Incra), buscou identificar a "importância da pequena produção [...] e de seu significado num quadro mais amplo, de desenvolvimento capitalista, no qual aparece e se desenvolve como produção subordinada" (p. IX). Além do seu recorte inovador, procurou evidenciar a importância econômica da pequena produção no país em um momento no qual se acreditava que ela estava fadada à extinção.

A partir do final da década de 1980 e principalmente durante a de 1990 alterou-se significativamente o direcionamento das investigações e os enfoques teóricos, momento em que pas-

2. A equipe foi composta por: Angela Kageyama, Elias Simon, Fernando Andrade e Souza, Flavio Abranches Pinheiro, Leonil de Servolo de Medeiros, Maria Rocha Antuniassi e Sonia Maria Pessoa Pereira. 
sou a predominar o uso da noção de agricultura familiar. Os trabalhos passavam a não mais buscar somente a condições precárias e de inferioridade desse segmento da agricultura (indícios do seu fim eminente), mas a procurar mostrar a sua importância socioeconômica, a diversidade, a capacidade produtiva e, acima de tudo, que a forma de exploração familiar foi a grande responsável pelo significativo desenvolvimento da produção de alimentos no Brasil e em grande parte do mundo desenvolvido. Nesse novo cenário se insere a breve apresentação a seguir dos principais trabalhos que alavancaram esta noção no Brasil.

O artigo de Ângela Kageyama e Sônia Bergamasco Novos dados sobre a produção familiar no campo (1989), apresentado ao XXVII Congresso da Sociedade Brasileira de Economia e Sociologia Rural (Sober), teve o mérito de fazer uma proposta inovadora de análise dos dados do Censo Agropecuário de 1980, introduzindo a variável do trabalho familiar para classificar os estabelecimentos agropecuários que faziam uso de gestão e trabalho contratado das que não separavam a gestão e trabalho, exercidos pela família agricultora. Neste estudo, mesmo tendo encontrado grande heterogeneidade de tipos de unidades de exploração familiares, as autoras constataram que a agricultura com base no trabalho familiar representava cerca $71 \%$ dos estabelecimentos agrícolas e correspondia a $42,3 \%$ da área total e $74 \%$ do pessoal ocupado na agricultura. Sendo, portanto, um segmento da maior importância.

Os livros de Ricardo Abramovay, Paradigmas do capitalismo agrário em questão (1992/1998), e de José Eli da Veiga, Desenvolvimento agrícola: uma visão histórica (1991) ${ }^{3}$, procuraram mostrar como a configuração da moderna agricultura dos países do capitalismo central se apoiou em uma forma social de organização do trabalho e de empresa específica: a "empresa familiar". Os seus

3. Cabe observar que Abramovay e Veiga mantiveram relações de colaboração, pesquisa e de assessoria com organizações sindicais desde os anos de 1980 e 1990. Em função deste transito, seus trabalhos, em alguma medida, dialogam com as questões do sindicalismo. trabalhos colocaram em questão os dois principais paradigmas teóricos que vigiam até aquele momento: um que preconizava que o avançar do capitalismo no campo desestruturava as explorações familiares e fortalecia a grande empresa fundada no trabalho assalariado (Kautsky e Lenin); outro que, inversamente, percebia a agricultura camponesa convivendo e até mesmo resistindo no capitalismo (Chayanov). ${ }^{4}$ Enquanto o livro de Veiga demonstrou que o modelo de agricultura dos países do capitalismo avançado foi baseado em explorações familiares, Abramovay tomou a realidade dos mesmos países para realizar uma distinção conceitual entre o significado desta agricultura familiar moderna, do presente, e da agricultura camponesa, do passado (FAVARETO, 2007). Inserido nessa diferenciação conceitual, na ótica de Abramovay, o uso da noção de "pequena produção" no Brasil e em outros países seria inapropriada, pois esconderia uma diferença fundamental entre formações sociais na agricultura muito distintas:
O que se escamoteia sob o nome de "pequena produção" é o abismo social que separa cam- poneses - para os quais o desenvolvimento do capitalista significa a fatal desestruturação - de agricultores profissionais - que vem se mostrando capazes não de sobreviver (porque não são resquícios de um passado em via mais ou menos acelerada de extinção), mas de for- mar a base fundamental do progresso técnico e do desenvolvimento do capitalismo na agri- cultura contemporânea (ABRAMOVAY, 1998, p. 211, grifos do autor).

Em suma, na ótica destes autores, a agricultura familiar corresponde a um modelo de organização da agropecuária centrada na "empresa familiar" que têm vantagens sociais, econômicas

4. A perspectiva chayanoviana também influenciou trabalhos acadêmicos no país. Principalmente no Museu Nacional da Universidade Federal do Rio de Janeiro foram realizadas pesquisas com esta inspiração e acompanhando o debate europeu da década de 1970 (Tepicht, Shanin, Amin e Vergopoulos). Destacam-se trabalhos de Moacir Palmeira, Lygia Sigaud, José Sérgio Lopes, Afrânio Garcia, entre outros. 
e ambientais (por ser mais democrática, eficiente e sustentável) quando comparada ao modelo patronal (modelo construído em oposição ao familiar, como empresas especializadas, racionalizadas, impessoais e que a agricultura pode ser somente mais um negócio entre outros). Os agricultores familiares seriam certa camada de agricultores capazes de se adaptar às modernas exigências do mercado, que se diferenciam dos demais pequenos produtores incapazes de assimilar tais modificações. A ideia central é a de que o agricultor familiar é um ator social da agricultura moderna e, de certa forma, ele resulta da própria atuação do Estado (o exemplo é da realidade europeia pesquisada pelos autores) que apostou nas explorações familiares, seja por interferências na estrutura agrária, seja na definição de políticas de preços e nos níveis de renda agrícola e no processo de inovação técnica.

Seguindo um caminho um pouco diferente da perspectiva destes autores, os dois livros que são resultado de uma pesquisa internacional coordenada por Lamarche A agricultura familiar I: comparação internacional (1993) e A agricultura familiar II: do mito à realidade $(1998)^{5}$ e o artigo de Wanderley Raízes históricas do campesinato brasileiro (1996), mostraram a diversidade de configurações que a agricultura familiar pode assumir em diferentes países. Os trabalhos coordenados por Lamarche mostraram a adaptação da agricultura familiar em contextos econômicos e políticos de países muito diversos (França, Canadá, Polônia, Brasil e Tunísia) e o seu objetivo foi apontar como, sob a lógica familiar, podem se organizar formas de exploração que variam desde aquelas mais próximas à autonomia camponesa até aquelas plenamente inseridas em mercados (FAVARETO, 2007). Neste aspecto, Lamarche deixa claro que a diversidade socioeconômica entre os países não esconde o fato de que o elemento unificador da variedade de situações encontradas no universo empírico é o caráter familiar da gestão, do trabalho e da posse da terra, pois "a explora-

5. Neste trabalho de pesquisa internacional fez parte uma equipe brasileira, composta por Maria Nazareth Wanderley, Fernando Lourenço, Anita Brumer e Ghislaine Duque. ção familiar não é um elemento da diversidade, mas contém nela mesma toda esta diversidade" (LAMARCHE, 1993, p. 18).

Deste esforço de pesquisa internacional foi elaborada uma proposta conceitual que reconhece uma significativa variabilidade dada pelas distintas posições que opera a "lógica familiar" nas relações sociais e da sua dependência ao mercado. Foram construídos quatro modelos teóricos de exploração familiar: empresa, empresa familiar, agricultura camponesa ou de subsistência e agricultura familiar moderna (LAMARCHE, 1998). Apresenta para o caso brasileiro a predominância de dois modelos: agricultura camponesa de subsistência e agricultura familiar moderna. Nos dois modelos, o estudo ressalta a predominância da mão de obra familiar enquanto estratégica, mesmo onde há a presença do trabalho contratado, e a busca incessante pelo acesso estável à terra. Ao contrário de Abramovay e Veiga, que veem a agricultura familiar de forma mais restrita, como uma empresa familiar, Lamarche entende que agricultura familiar é formada por uma diversidade de situações nas quais opera a lógica familiar, evidenciadouma rica heterogeneidade e uma enorme capacidade de adaptação das explorações de tipo familiar em diversos países.

Maria Nazareth Wanderley participou da pesquisa internacional coordenada por Lamarche e revelou, em trabalho mais recente, que essa experiência de pesquisa permitiu "recolocar o eixo das reflexões" das pesquisas que eram desenvolvidas no Brasil, "centrado não mais nas razões da sobrevivência do campesinato, já que existência deste era incontestável, mas no lugar que ele ocupa" (WANDERLEY, 2009, p. 15). Com essa constatação se tratava então de compreender o agricultor familiar como um ator social participante pleno do progresso, da sociedade em geral, e mais diretamente, das transformações da agricultura e do meio rural. Trata-se, pois, de buscar apreendê-los como protagonistas de sua própria história.

Algumas dessas ideias foram apresentadas originalmente em um artigo apresentado por Wanderley em 1996 no XX Encontro Anual da Associação Nacional de Pós-graduação e Pesquisa 
em Ciências Sociais (Anpocs). Neste artigo, faz um resgate sobre as "raízes históricas do campesinato brasileiro" ao mesmo tempo em que demarca sua posição no debate sobre a agricultura familiar no Brasil. Argumenta que a noção de "agricultura familiar" deve ser entendida de forma genérica: "como aquela em que a família, ao mesmo tempo em que é proprietária dos meios de produção, assume o trabalho no estabelecimento produtivo" (p. 2). O caráter familiar desse modelo de agricultura não é um mero detalhe superficial e descritivo, mas "o fato de uma estrutura produtiva associar família-produção-trabalho tem consequências fundamentais para a forma como ela age econômica e socialmente" (p. 2). Sobre este tema da estratégia familiar como central, Wanderley (2009) argumenta de forma complementar, em outro trabalho, que

mais do que a diferença quanto aos níveis de renda auferida, que apenas reconstrói o perfil momentâneo dos agricultores familiares, é a diferenciação das estratégias familiares que está na origem da heterogeneidade das formas sociais concretas da agricultura familiar (p. 15).

Ao contrário do que defendem Abramovay e Veiga, Wanderley argumenta que o agricultor familiar não é um personagem novo na sociedade contemporânea (produto da ação do Estado, das políticas de modernização da agricultura) desvinculado do seu passado camponês, mas, ao contrário, os agricultores familiares seriam portadores de elementos de ruptura com o seu passado camponês, ao mesmo tempo em que mantêm algumas continuidades. Nas palavras de Wanderley (2003): os agricultores familiares "são portadores de uma tradição (cujos fundamentos são dados pela centralidade da família, pelas formas de produzir e pelo modo de vida), mas devem adaptar-se às condições modernas de produzir e de viver em sociedade" (p. 47-48) uma vez que estão inseridos em mercados modernos e são influenciados pela sociedade englobante e pelo Estado.

Em função desse duplo caráter da agricultura familiar, Wanderley (2003) argumenta o que concede aos agricultores modernos a condição de atores sociais, construtores e parceiros de um projeto de sociedade - e não simplesmente objetos de intervenção do Estado, sem história - é precisamente a dupla referência à continuidade e à ruptura (p. 47).

Nesse sentido, a proposta conceitual desenvolvida por Wanderley é mais ampla permitindo evidenciar as "raízes camponesas" do agricultor familiar moderno ao mesmo tempo em que permite encontrar os atores sociais (organizações) e os agricultores participando do seu próprio processo de construção (o seu "fazer-se" cf. THOMPSON, 1987) enquanto agricultores familiares.

Além destes trabalhos acadêmicos, também tiveram importante repercussão, particularmente na definição de políticas públicas, algumas pesquisas elaboradas por meio do convênio de cooperação técnica da $\mathrm{FAO} / \mathrm{Incra}$, coordenados por Carlos Guanziroli. Um primeiro estudo realizado no ano de 1994 teve como objetivo declarado: elaborar diretrizes para "uma nova estratégia de desenvolvimento rural para o Brasil". Dentre as suas principais contribuições fez uma sugestão de classificação dos estabelecimentos agropecuários brasileiros em dois modelos: um "patronal" e outro "familiar". O "modelo patronal" teria como característica a separação entre gestão e trabalho, a organização descentralizada, a ênfase na especialização produtiva e em práticas agrícolas padronizáveis, o uso predominante do trabalho assalariado e a adoção de tecnologias dirigidas à eliminação das decisões "de terreno" e "de momento" (intuitivas ou de senso comum). Já o "modelo familiar" teria como característica uma relação íntima entre trabalho e gestão, a direção do processo produtivo assegurada diretamente pelos proprietários, a ênfase na diversificação produtiva e na durabilidade dos recursos e na qualidade de vida, a utilização do trabalho assalariado em caráter complementar e a tomada de decisões imediatas, adequadas ao alto grau de imprevisibilidade do processo produtivo (FAO/ INCRA, 1994, p. 2). 
No interior do modelo familiar foi feita ainda uma classificação em três tipos de unidades familiares de produção, a saber: familiar "consolidada" (com área de terra média de 50 ha); em "transição" (com área média de 8 ha); e "periférica" (com área média de 2 ha). Com base nessa classificação, o documento da $\mathrm{FAO} /$ Incra propõe como "público alvo" para a construção prioritária de políticas públicas a categoria dos agricultores familiares em "transição", pois argumenta que "fortalecer e expandir a agricultura familiar significa, antes de tudo, dar respostas às dificuldades que enfrentam os produtores familiares fragilizados", mas que tem "potencial" para transformarem-se em "empresas familiares viáveis" (IDEM, p. 5). Quanto aos "consolidados", estes não necessitariam de auxílio público especial. E os "periféricos", não sendo viáveis economicamente, só se poderia pensar para eles em políticas sociais de combate à pobreza. A criação do Pronaf seguiu esta orientação de uma política de auxílio aos agricultores em "transição", os que poderiam ser viabilizados na produção.

\section{Organizações de agricultores e Estado: embates e a definição dos primeiros contornos da agricultura familiar}

A gênese de um grupo social não deve ser entendida apenas pelos processos econômicos ou pelas elaborações teóricas que orientam as ações dos atores, mas também devem ser levadas em conta as experiências de organização política e as posições que os atores assumem no campo político (THOMPSON, 1987; BOURDIEU, 2005). No caso dos agricultores familiares, o seu aparecer político é produto de sua própria experiência de "fazer-se" enquanto atores políticos, com identidade e projeto próprios, em diálogo com as elaborações acadêmicas e em uma relação ora conflitiva, ora de colaboração com setores do Estado (MEDEIROS, 2001; PICOLOTTO, 2011).

Desde meados dos anos de 1980 os "pequenos produtores" vinham ganhando espaços no interior do sindicalismo dos trabalhadores rurais, construindo novas lideranças e dando visibilidade e importância para as suas demandas. Realizaram grandes mobilizações por melhores condições de produção e preços dos produtos recebidos (uva, leite, soja, fumo, suínos) ${ }^{6}$, contra a política econômica do governo, considerada prejudicial aos agricultores e na pressão pela definição de uma política agrícola diferenciada para os pequenos produtores (MEDEIROS, 1989, 2001; ROMANO, 1996; PICOLOTTO, 2011). Sobre este último ponto, tanto a Contag quanto o Departamento Nacional dos Trabalhadores Rurais (DNTR) da Central Única dos Trabalhadores (CUT) apresentaram projetos de política agrícola diferenciada para a formulação da Lei Agrícola no final dos anos de 1980 e início dos 907. Nas proposições aparecem os contornos iniciais do projeto da agricultura familiar assumido pelo sindicalismo nos anos seguintes, tais como: a proposição de instrumentos de política agrícola diferenciados (crédito, subsídios, seguro agrícola, assistência técnica etc.) para os pequenos produtores; e a definição de critérios para a classificação dos agricultores que deveriam ser os beneficiários da política, nos seguintes termos: aqueles que fazem uso do trabalho da família no estabelecimento, sem concurso de empregados permanentes, mas com um limite de área de três módulos rurais para o projeto da Contag e até cinco módulos para o do DNTR/CUT.

Ainda que tenham conseguido inserir no texto da Lei Agrícola um "princípio de política agrícola diferenciada" para os pequenos produtores (DELGADO, 1994, p. 11), é importante perceber que as propostas levantadas pelo sindicalismo dos trabalhadores no campo de forças que se constituiu na definição da Lei assumem uma posição minoritária (de "oposição agrária", cf. DELGADO, 1994). Neste campo, enfrentavam as

6. Os produtores de soja, por exemplo, chegaram a mobilizar 700 mil agricultores nos estados do Sul e Mato Grosso do Sul em 1980 (Medeiros, 1989).

7. A Contag elaborou o documento Proposta do Movimento Sindical de Trabalhadores Rurais para as Leis Agrária e Agrícola em 1989 e o DNTR/CUT o documento Proposta para um Projeto de Lei Agrícola em 1990. 
forças políticas majoritárias da Frente Ampla da Agropecuária Brasileira que aglutinava os setores patronais rurais e fizeram valer os seus interesses na definição do texto legal. Coube aos pequenos a conquista desta diferenciação ${ }^{8}$ e, posteriormente, as lutas pela sua concretização.

A agenda liberalizante do Estado brasileiro da década de 1990, iniciada no governo Collor, confrontada com as novas possibilidades de participação social abertas com a Constituição de 1988, colocou as organizações sindicais em uma posição ambígua em relação ao Estado: em algumas situações se posicionaram em oposição frontal às políticas de abertura comercial e desregulamentação das obrigações do Estado; em outras, lhes foi propiciado oportunidades de serem propositivas com o Estado (nos conselhos e fóruns de políticas) e colaborar no desenho de algumas políticas públicas. O acordo do Mercosul, por exemplo, onde o Brasil passava a ser um exportador de produtos industrializados e importador de produtos agrícolas da Argentina e Uruguai (DELGADO et al., 1996), foi visto pelas organizações de agricultores como uma grande ameaça para os pequenos produtores. A partir de 1993, no governo Itamar Franco, foram realizados diversos seminários em estados do Sul e do Sudeste brasileiro para debater a integração destes produtores no Mercosul, centrando-se, especialmente, na reivindicação de políticas agrícolas diferenciadas para reestruturar e reconverter as pequenas propriedades afetadas. Eventos semelhantes também ocorreram com organizações de agricultores dos demais países membros (ROMANO, 1995; CONTAG, 1994).

Outros fatores que contribuíram para a construção das propostas políticas feitas pelo sindicalismo no processo de formação do Mercosul foram os intercâmbios, as viagens de lideranças e atividades de formação realizadas com organizações de agricultores, Igrejas, ONGs e agências

8. Ao que pese essa diferenciação, consta a prioridade do Estado em oferecer serviços de assistência técnica gratuita, crédito subsidiado, geração e adaptação de tecnologias agrícolas aos pequenos agricultores além de ter previsto a concessão de "crédito rural especial e diferenciados aos produtores rurais assentados em áreas de reforma agrária" (Lei Agrícola, n. 8.171 de 1991, art. 52). de solidariedade europeias para conhecer as suas experiências (principalmente na França e na Alemanha). A experiência de integração regional da União Europeia, a sua Política Agrícola Comum e as ações das organizações de agricultores familiares nesse processo foram vistas como uma forma de subsidiarem a intervenção do movimento sindical no Brasil. O conhecimento deste modelo de agricultura familiar (predominante em boa parte da Europa), fomentado por políticas de Estado, ajudou a embasar os projetos de agricultura das organizações de agricultores brasileiras e a assumir uma postura propositiva perante o Estado.

Como resultado, passou-se de uma postura defensiva de mera defesa dos pequenos produtores que estavam sendo excluídos progressivamente do processo produtivo, para a adoção de uma linha propositiva. Em 1994, constituiu-se no âmbito do Ministério da Agricultura, Abastecimento e Reforma Agrária (Maara) uma Comissão Técnica do Pequeno Produtor (Portaria MAARA 682/93 e 42/94) em conjunto com a Contag para analisar temas relacionados à pequena produção e formação de propostas na área de políticas agrícola. Como resultado dos trabalhos dessa Comissão foi publicado um relatório com o sugestivo título "Propostas e recomendações de política agrícola diferenciada para o pequeno produtor rural" (MAARA/CONTAG, 1994). Nesse relatório, era feita uma série de propostas e recomendações para adequar a política agrícola. Dentre estas, as mais destacadas diziam respeito à classificação dos pequenos produtores e a proposta de crédito diferenciado para esse público. A nova classificação dos pequenos produtores rurais estabelecia critérios importantes que passariam a ser adotados na definição de políticas desse período em diante, a saber:

É considerado pequeno produtor rural aquele que explore parcela de terra na condição de proprietário, posseiro, arrendatário, parceiro ou ocupante atendendo simultaneamente aos seguintes requisitos: a) utilização do trabalho direto e pessoal do produtor e sua família, sem concurso do emprego permanente, sendo 
permitido o recurso eventual à ajuda de terceiros, quando a natureza sazonal da atividade agrícola exigir; b) que não detenha, a qualquer título, área superior a quatro módulos fiscais, quantificados na legislação em vigor9; c) que $80 \%$ de renda familiar do produtor seja originária da exploração agropecuária e/ou extrativa; d) que o produtor resida na propriedade ou em aglomerado rural ou urbano próximo (MAARA/CONTAG, 1994, p. 9-10).

Estes critérios se aproximam dos critérios de classificação do pequeno produtor defendidos pela Contag na Lei Agrícola, guardadas algumas diferenças. São introduzidos os critérios de moradia na propriedade e sobre a necessidade de $80 \%$ da renda ser proveniente da exploração agropecuária, ligada à preocupação do sindicalismo para que as políticas diferenciadas fossem exclusivamente designadas a agricultores propriamente ditos. Ao que pese estas preocupações, elas se ligam às disputas sobre o recorte da base social do sindicalismo entre grupos internos e com os setores patronais. Quais categorias sociais deveriam este sindicalismo representar e demandar políticas do Estado? Que tamanho de área poderiam possuir os pequenos proprietários representados pelo sindicalismo de trabalhadores rurais?

Os pequenos proprietários desde a década de 1970 tentavam ampliar sua presença no interior da Contag (PALMEIRA, 1985; MEDEIROS, 1989). As federações sindicais dos estados do Sul e de São Paulo, onde a presença de pequenos proprietários era maior, questionavam o uso do critério de um módulo rural para enquadrá-los no sindicalismo de trabalhadores. Defendiam a livre escolha para os que trabalhavam em "regime de economia familiar", sem critérios de tamanho de área. Opunham-se a esta livre entrada dos pequenos produtores as federações do Nordeste e as de outros estados, receosas com uma possível descaracterização sindical. Argumentavam que o sindicalismo deveria ser exclusivamente de

9. Este critério também foi influenciado pelo que estabelece a Lei Agrária (n. 8.629 de 1993). A Lei definiu por "pequena propriedade" o imóvel que possui "área compreendida entre 1 (um) e 4 (quatro) módulos fiscais". trabalhadores que tivessem identidade de interesses comuns, que os produtores (que podiam até ser de tamanho "médio", segundo diferentes padrões) teriam pouca afinidade com os assalariados e os pequenos proprietários; que teriam um nível de vida superior e que seus interesses podiam ser diversos e até mesmo contraditórios. Há que se considerar, também, que esta mudança também poderia provocar um aumento do número de filiados nas federações do Sul e outras regiões causando possíveis mudanças na correlação de forças no interior do sindicalismo. Como resultado destes debates se chegou a um acordo entre os congressos da Contag de 1979 e 1985: com a ampliação até dois módulos para o reconhecimento dos pequenos proprietários em regime de economia familiar e sem empregados permanentes (HELLER DA SILVA, 2006; PICOLOTTO, 2011). Entretanto, como se observou no Projeto de Lei Agrícola da Contag e na proposta de nova classificação dos pequenos produtores feita pela comissão Maara/Contag, os critérios de reconhecimento dos pequenos produtores variaram até três ou quatro módulos. Esta ampliação mostrava a maior importância que esta categoria passava a ter no sindicalismo e a sua capacidade de interferir nas decisões internas e na negociação de políticas públicas.

Este debate sobre as categorias a serem representadas pelo sindicalismo de trabalhadores rurais também ocorreu na CUT, mas com outros contornos. O debate se tornou público com dois artigos vinculados na revista Teoria e Debate. Um primeiro artigo intitulado Limpar o terreno, Paulo de Tarso Venceslau (1989) fez uma dura crítica à estrutura sindical rural corporativista (herdada da "ortodoxia da esquerda" e da legislação sindical da ditadura) e a unificação das diversas categorias que o compõe, a saber; assalariados, pequenos proprietários e produtores sem terra. Na sua ótica, esta herança faz conviver no mesmo sindicato "classes distintas", tratadas "como iguais". Não seria adequado estarem em uma mesma Central assalariados rurais e pequenos proprietários (que dispõem de meios de produção e que podem contratar assalariados). Por fim, o autor questiona: 
"Cabe à CUT lutar por preços mínimos, organizar comercialização ou propor uma política agrícola?" Segundo seu juízo, a resposta deveria ser negativa, ela deveria se limitar às demandas de assalariados. Por ser uma Central de trabalhadores, deveria deixar de representar pequenos proprietários. Entretanto, a proposta de Venceslau aparecia como despropositada frente às reais bases rurais da CUT. Suas bases no campo e as suas principais lideranças de destaque nacional eram formadas por pequenos proprietários do Sul e do Norte do país. Em resposta ao artigo de Venceslau, Regina Novaes publicou o artigo Dissolvendo a neblina, argumentando que a construção de uma central sindical da classe trabalhadora não se dá somente na demarcação objetiva do que seria a classe, da "classe em si" (definida pelo lugar na produção). Ao contrário, as classes se constituem em suas inter-relações, a "classe para si" (com consciência e projeto próprio) só se constitui no conflito entre classes, em uma relação de oposição. Desta forma, uma "central sindical que se quer 'classista' não poderia excluir pequenos produtores que, em sua luta, questionam a via ou o modelo que tem permitido a acumulação e o desenvolvimento do modo de produção capitalista no país" (NOVAES, 1989). Nesta acepção, a classe trabalhadora que a CUT pretende representar não se encontra pronta no mundo do trabalho à espera de ser conduzida pelo sindicalismo. A classe só existe, enquanto "classe para si", como resultado da ação do sindicalismo (e os demais atores sociais) na construção de seus projetos de porvir e debatendo-se com seus adversários sociais. ${ }^{10}$

Com os esclarecimentos que este debate proporcionou, saiu fortalecido o lugar dos pequenos produtores na CUT, mas também fez aprofundar a discussão sobre a necessidade de criação de sindicatos diferenciados por categoria na base da CUT, tais como: assalariados rurais e agricultores familiares.

10. A argumentação de Novaes se aproxima da noção de classe de Thompson, para quem classe é "relação histórica". Em suas palavras: "A classe operária não surgiu tal como o sol numa hora determinada. Ela estava presente no seu próprio fazer-se" (THOMPSON, 1987, p. 9).

\section{O sindicalismo assume a agricultura familiar}

Foi neste rico debate no meio sindical que foi incorporada na linguagem política a categoria agricultura familiar, em um primeiro momento nos documentos do DNTR/CUT, logo em seguida também pela Contag. O primeiro documento oficial que utilizou esta categoria na linguagem sindical foi o caderno de tese do II Congresso Nacional do DNTR/CUT, realizada de 25 a 28 de março de 1993, em que era estabelecido como objetivo maior da organização a construção de um Projeto Alternativo de Desenvolvimento, que garanta o "fortalecimento da agricultura familiar como prioridade do desenvolvimento agrícola" (DNTR/CUT, 1993, p. 19).

A incorporação desta categoria viria a renovar as bandeiras do sindicalismo e ajudar a superar certa crise que se abateu no sindicalismo dos trabalhadores rurais no final da década de 1980 e início de 1990 (NOVAES, 1997; FAVARETO, 2006). Uma das iniciativas mais ousadas com vistas a resolver a crise se deu com o processo de unificação da Contag com o DNTR/CUT, com extinção deste último ${ }^{11}$. No esforço de unificar o sindicalismo ocorreram eventos importantes que mostravam a força e o potencial que a união dos atores do campo (DNTR/CUT, CONTAG, MST, entre outros) poderiam ter, tais como: a construção dos Gritos da Terra Brasil (a partir de 1994), como uma forma de mobilização massiva de âmbito nacional e com objetivo de propor e negociar políticas com os governos; a formulação do Projeto Alternativo de Desenvolvimento (descrito nos parágrafos seguintes) e a conquista de importantes políticas públicas de apoio à agricultura familiar, como o Pronaf, em 1995. Sobre o Pronaf é significativo perceber que esta política foi inspirada no modelo teórico elaborado pelo convênio FAO/Incra (1994) e na sua sugestão de priorizar o apoio aos agricultores familiares "em transição" e os critérios de acesso aos beneficiários foram

11. Mais detalhes sobre a unificação do DNTR/CUT e da Contag ver Picolotto (2011) e Favareto (2006). 
buscados na classificação dos pequenos produtores (agora renomeados de agricultores familiares) definidos pela Comissão Maara/Contag de 1994. Neste sentido, é a concretização de uma política negociada pelo sindicalismo com o governo desde o início da década e inscrita no princípio de política agrícola diferencia (crédito com subsídios) previsto na Lei Agrícola.

Este foi um momento de mudanças da forma de agir do sindicalismo e da sua relação com o Estado. Passava de uma perspectiva de um sindicalismo reivindicatório (marcado fortemente por mobilizações e reinvindicações da década de 1980) para um sindicalismo propositivo (que faz mobilizações, mas que tem propostas concretas, um projeto para a agricultura e para o país). Nesta nova estratégia, a formulação de um projeto alternativo de desenvolvimento assume lugar central e a agricultura familiar passa a ser a depositária das maiores expectativas do sindicalismo da Contag/CUT.

A construção do projeto alternativo esteve no centro das preocupações do sindicalismo na segunda metade da década de 1990, principalmente com a realização de um ambicioso projeto entre os anos de 1996 e 1999, o chamado Projeto CUT/Contag de Pesquisa e Formação Sindical, que envolveu o sindicalismo e importantes pesquisadores acadêmicos na sua assessoria ${ }^{12}$. Esse conjunto de iniciativas resultou na elaboração do que ficaria conhecido como o Projeto Alternativo de Desenvolvimento Rural Sustentável (PADRS), assumido oficialmente pelo sistema sindical da Contag no VII Congresso de 1998. Esse projeto, mais do que um conjunto de medidas pontuais, procurava, através de análise de experiências concretas, traçar orientações gerais de um novo modelo de desenvolvimento para o campo brasileiro: defendia a necessidade de realização da reforma agrária, optava pela agricultura familiar como formato de agricultura desejável, defendia

12. OProjeto contou com a assessoria no eixo Desenvolvimento Rural de José Eli da Veiga da USP e no eixo Organização Sindical com Leonilde Medeiros do CPDA/UFRRJ e de Regina Reyes Novaes da UFRJ. novas formas de organização da produção, política agrícola diferenciada e políticas que vão além da produção, tais como: educação, saúde, lazer, previdência e assistência social, formação profissional, pesquisa e assistência técnica, entre outras (CONTAG, 1998).

Os resultados deste processo de unificação sindical e da adoção da agricultura familiar como público prioritário do sindicalismo produziram mudanças significativas. Em primeiro lugar, ocorreu uma mudança na configuração de forças na interior da Confederação. Se desde a sua fundação na década de 1960 até o início da década de 1990, as pautas prioritárias foram a reforma agrária e os direitos trabalhistas, com lideranças nordestinas nos seus postos principais, com certo realinhamento interno que vinha ocorrendo desde a década de 1980, a entrada dos cutistas e adoção do PADRS, foi eleita a agricultura familiar como prioritária e o eixo de poder interno se deslocou. Em segundo lugar, o modelo da agricultura familiar adotado pela Contag teve fortes contos sulistas (BONATO, 2003). A agricultura familiar visualizada como modelo foi a de origem "colona" (pequenos proprietários de origem imigrante), marcada pela propriedade familiar, pela perspectiva de integração aos mercados, moderna ou em vias de modernização. Para estes, a principal demanda de política pública era crédito para produção, demanda que o Pronaf supriu. Por fim, o sindicalismo assumiu uma postura propositiva perante os governos, foi gradativamente se inserindo em espaços de gestão de políticas públicas, alterado sua forma de ação questionadora, de "oposição agrária", que marcou sua trajetória na década de 1980.

Estas novas orientações sindicais não foram unânimes entre os setores cutistas e motivaram desacordos políticos com antigos aliados. Setores cutistas descontentes deram origem ao Movimento dos Pequenos Agricultores (MPA) no Sul país e no estado do Espírito Santo, em 1996. Da mesma forma, o MST que sempre fora um aliado próximo, por discordar destas novas perspectivas do sindicalismo passou a organizar, no 
final da década de 1990, a seção brasileira da Via Campesina ${ }^{13}$, como uma nova articulação de atores sociais separada do campo cutista. Na ótica destes atores, enquanto as organizações sindicais, adeptas da agricultura familiar, constroem um projeto de integração com os mercados agroindustriais (formando o que chamam de "pequenos capitalistas" ou "agronegocinho"), os movimentos da Via Campesina têm procurado construir um projeto de "autonomia camponesa" no capitalismo (FERNANDES, 2012). Neste sentido, rompem com o projeto da agricultura familiar e fortalecem a identidade política de camponês, associada à perspectiva de um projeto de resgate e realização da autonomia camponesa no tempo presente.

De outra parte, alguns setores cutistas que compuseram a aliança inicial com a Contag, na passagem de século deflagraram uma nova dissidência. Dificuldades de várias ordens, como a não aceitação da filiação das organizações chamada de "diferenciadas", tais como a Federação dos Trabalhadores na Agricultura Familiar de SC (Fetrafesc), fundada em 1997 e sindicatos regionais de agricultores familiares nos estados do Sul (o que contrariava as recomendações do Projeto CUT/Contag de equacionar as experiências de renovação da estrutura sindical), disputas de direção da Contag e o fortalecimento de um movimento de afirmação da agricultura familiar na região Sul do país (que agregou sindicatos, cooperativas e ONGs) deram base para formaçãoda Federação dos Trabalhadores na Agricultura Familiar (FETRAF) em 2001. A Fetraf surgiu como uma nova organização sindical de âmbito regional e que logo em seguida se nacionalizou. Trata-se uma organização sindical orgânica da CUT, que procura fazer sua ligação histórica com o antigo DNTR/CUT e se propõe a ser um ente sindical que representa especificamente os agricultores familiares nas regiões que atua. Passou a ser uma organização concorrente da Contag (PICOLOTTO, 2014).

13. A seção brasileira da Via Campesina foi formada em 1999. Conta também com os Movimentos dos Atingidos por Barragens, das Mulheres Camponesas, Comissão Pastoral da Terra, entre outros (FERNANDES, 2012).

\section{Reconhecimento formal da agricultura familiar}

No final do primeiro governo de Fernando Henrique Cardoso (1995-1998), foi criado o Ministério do Desenvolvimento Agrário (MDA) para tratar das questões relacionadas à agricultura familiar e à reforma agrária, enquanto o Ministério da Agricultura, Pecuária e Abastecimento (Mapa) ficava responsável pelas atividades agropecuárias empresariais (do chamado "agronegócio"). A constituição desses dois ministérios expressava

o reconhecimento tenso e conflitivo pelo Estado brasileiro da existência desses dois tipos de agricultura que, embora não sejam independentes em sua dinâmica, são portadores de propostas antagônicas de desenvolvimento rural (LEITE et al., 2007, p. 15).

O MDA, mesmo não sendo o responsável exclusivo por políticas para o segmento da agricultura familiar, desde a sua origem acabou concentrando boa parte das ações direcionadas a este público.

A criação do Pronaf, em 1995, foi vista amplamente como um reconhecimento da especificidade da agricultura familiar. Mesmo com a mudança de governo em 2003, com o governo Lula ele continuou a ser o principal instrumento de política agrícola direcionado para esse público. No que se refere ao volume de recursos disponibilizados para o Programa entre 2003 e 2010, observa-se uma ampliação de quase três vezes (de 5,4 milhões para 16 milhões), com redução das taxas de juros, a ampliação do valor passível de financiamento e a diversificação das modalidades, com a criação de várias novas, dentre as quais: Mulher, Jovem, Agroindústria, Agroecologia, Semiárido, Floresta, Eco, Turismo Rural, Pesca e Mais Alimentos (GRISA e WESZ JR., 2010).

A composição da gestão do MDA nos governos Lula e Dilma contou com a participação de quadros ligados aos movimentos sociais e sindicais. Esta participação no bloco no poder (ainda que de forma subordinada, em um minis- 
tério com menor importância política e recursos do que o MAPA) possibilitou maior influência destas organizações na formulação e na execução de algumas políticas públicas de apoia a agricultura familiar. Nestes governos, foram criadas diversas políticas para o setor da agricultura familiar, que vão além das já existentes relacionadas ao crédito, tais como: Programa de Garantia de Preços da Agricultura Familiar (PGPAF), o Seguro da Agricultura Familiar (Seaf), o Programa Garantia de Safra, Programa de Aquisição de Alimentos da Agricultura Familiar (PAA), Política Nacional de Assistência Técnica e Extensão Rural (PNATER), Programa Nacional de Habitação Rural (PNHR), Programa de Desenvolvimento Sustentável dos Territórios Rurais (PDSTR), Programa de Agroindustrialização da Agricultura Familiar, Programa Nacional de Crédito Fundiário (PNCF), Luz para Todos, Arca das Letras, Programa Nacional de Acesso ao Ensino Técnico e Emprego (Pronatec), entre outras.

Esta nova relação com o Estado tem sido associada com a ideia da "cogestão" das políticas públicas (SABOURIN, 2014), mas também pode ser relacionada, de forma mais ampla, com a conformação de relações baseadas no que tem sido chamado de "neocorporativismo": forma de relação entre Estado e sociedade civil que visa reduzir os conflitos entre as classes e grupos sociais e as suas interações com setores estatais, preservando certa autonomia das organizações sociais (o que difere esta condição do corporativismo tradicional, onde o Estado as subordinava e disciplinava), mas tornando as suas relações mais colaborativas, institucionalizadas e previsíveis (OFFE, 1989; GOLDIN, 2013).

De outra parte, a boa relação com setores estatais e a criação deste conjunto de políticas mostra o reconhecimento deste grupo de agricultores e das organizações de representação com boa interlocução pública. O reconhecimento alcançado com as políticas públicas não se dá somente nos aspectos produtivos, ligados à profissão e ao local no processo produtivo, mas incluem outras dimensões do mundo da vida, tais como: a habitação rural, a educação, a capacitação, o desenvol- vimento dos territórios rurais pensados em suas diversas dimensões, a cultura local etc. Trata-se de uma forma diferenciada de conceber o mundo rural, de tratar os agricultores como cidadãos, não somente como produtores.

Este reconhecimento também garantiu a criação de uma Lei da Agricultura Familiar (Lei n. 11.326, de 2006) que define oficialmente a "agricultura familiar" como "categoria profissional" e estabelece as diretrizes para a formulação da Política Nacional da Agricultura Familiar e Empreendimentos Familiares Rurais. Em seu Artigo 3o, a lei considera "agricultor familiar" aquele que pratica atividades no meio rural, atendendo aos seguintes requisitos: não detenha, a qualquer título, área maior do que quatro módulos fiscais; utilize predominantemente mão-de-obra da própria família nas atividades econômicas do seu estabelecimento ou empreendimento; tenha renda familiar predominantemente originada de atividades econômicas vinculadas ao próprio estabelecimento ou empreendimento; dirija seu estabelecimento ou empreendimento com sua família (BRASIL, 2006).

Essa definição de agricultura familiar, embora semelhante à definição elaborada em 1994 e usada pelo Pronaf, tem algumas diferenças: flexibiliza algumas exigências requeridas no Pronaf: indica que a renda deve ser predominantemente de atividade vinculada ao estabelecimento (eliminado a necessidade de $80 \%$ de a renda ser da atividade agropecuária) e elimina a exigência de residência na propriedade ou em povoado próximo. Em relação aos grupos sociais que são beneficiários, tanto o Pronaf quanto a Lei incluem como beneficiárias categorias sociais rurais que vivem e trabalham em situações análogas à agricultura familiar, tais como: silvicultores, aquicultores, extrativistas e pescadores.

A Lei objetivou englobar a diversidade de situações de trabalho familiar rural nos mesmos instrumentos legais. Se, de um lado, esta unificação fortalece as bases legais de reconhecimento da agricultura familiar e a torna definidora de direitos e políticas públicas para categorias sociais diversas, de outro, esconde as diferenças exis- 
tentes no meio rural brasileiro ao associar esta diversidade de situações à categoria agricultura familiar. Nos anos mais recentes algumas destas categorias têm reacendido demandas por reconhecimento de diferenças, por visibilidade pública e por políticas públicas específicas, que atendam suas particularidades, como os pescadores, os extrativistas, quilombolas, entre outros.

\section{A agricultura familiar para o sindicalismo: reconhecimento social, projeto político e espaço de vida}

Como mostrado ao longo do texto, a incorporação da categoria agricultura familiar pelas organizações sindicais não se deu de forma passiva frente às elaborações de outros agentes. Enquanto nas políticas públicas de apoio à agricultura familiar, em trabalhos acadêmicos sobre o tema e na própria Lei da Agricultura Familiar são feitas definições mais genéricas e normativas do que seria a agricultura familiar, seja a caracterizando como empresa familiar e como herdeira do campesinato, seja a delimitando como unidade de exploração familiar com área de até quatro módulos fiscais, com força de trabalho predominantemente da família, que reside na propriedade etc. Por sua vez, as organizações sindicais de agricultores, mesmo dialogando com essas definições, tendem a lançar acepções mais subjetivas, ligadas à especificidade da família agricultora, ao seu local de trabalho e de vida, à cultura local, à produção de alimentos, à tradição, à diversidade, associando-a a um valor positivo, como superação de uma condição de inferioridade social que historicamente lhe foi atribuída.

O sindicalismo procura mostrar que a construção da ideia-força agricultura familiar seria resultado de lutas políticas, culturais e morais por reconhecimento social. Esta perspectiva de luta por reconhecimento pode ser associada com a "teoria do reconhecimento" de Honneth (2009). Para este autor existem três formas possíveis de reconhecimento denegado: a) aquelas que afe- tam a integridade corporal dos sujeitos e, assim, sua autoconfiança básica; b) a negação de direitos, que mina a possibilidade de autorrespeito, à medida que inflige ao sujeito o sentimento de não possuir o status de igualdade com os outros e; c) a referência negativa ao valor de certos indivíduos e grupos sociais, que afeta a autoestimados sujeitos. Para a superação destas situações de reconhecimento denegado, os sujeitos "precisam além da experiência da dedicação afetiva e do reconhecimento jurídico, de uma estima social que lhes permita referir-se positivamente a suas propriedades e capacidades concretas" (HONNETH, 2009, p. 198). Assumindo, assim, "atitudes positivas" para com eles mesmos e perante os outros, na forma de "autoconfiança, autorrespeito e autoestima" (idem).

Em relação ao caso da emergência dos agricultores familiares como personagens políticos no Brasil, percebem-se alguns pontos de contato com esta teoria. No sindicalismo que deu origem à Fetraf, o início da discussão, em meados da década de 1990, sobre a adoção da categoria agricultura familiar mostra claramente uma tentativa de superação de uma condição de desrespeito social e de baixa autoestima. Segundo aponta Amadeu Bonato (assessor sindical), o início desta discussão ocorreu para substituir o termo "pequena produção" que era considerado pejorativo e escondia os personagens sociais envolvidos: "Nós fizemos um debate. Não se trata de discutir se a produção é ou não pequena. $O$ fato é que independente do tamanho da produção o que importa são os personagens e não o que produzem" (entrevista ao autor, 2010). De forma similar, o assessor sindical, Dino Castilhos, escreveu um texto para pensar a construção da identidade da agricultura familiar, texto que passaria a ser uma referência teórica importante para a Fetraf. Nesse texto, é analisado como os movimentos e partidos de esquerda, com base em suas tradições teóricas marxistas, concebem a chamada pequena produção, para chegar à conclusão de que as categorias pequena produção e agricultura familiar trazem em si distintas formas de ver os sujeitos presentes na agricultura e "diferentes concepções sobre 
o papel dos agricultores familiares" na sociedade e nos projetos de porvir:

Pequena produção revela uma formulação que deriva da compreensão de uma pequena produção capitalista incompleta e não desenvolvida. Ou seja, os pequenos agricultores são produtores atrasados e marginalizados no capitalismo, como são explorados fazem parte do proletariado agrícola [...] Já a expressão "agricultura familiar" procura designar uma forma de produção moderna e mais eficiente sob o ponto de vista econômico, social e ambiental (CASTILHOS, 1999, p. 4).

Nesta diferenciação teórica entre pequena produção e agricultura familiar fica evidente que a Fetraf não compactua com as teses marxistas clássicas que previam a decadência e mesmo a extinção das unidades familiares na agricultura. Ao contrário disso, busca fortalecer o segmento social da agricultura familiar, entendendo-a como um personagem do mundo contemporâneo. Um sujeito do desenvolvimento do mundo rural.

A construção da identidade da agricultura familiar, então, busca livrar-se do caráter atrasado, imperfeito e incompleto que a noção de pequena produção carregava e motivar a sua ressignificação ao ser renomeada como agricultura familiar, dando-lhes novos adjetivos positivos, tais como: produtora de alimentos, moderna, eficiente, sustentável etc. Nesta elaboração, percebe-se uma clara tentativa da Federação motivar os agricultores a livrarem-se de uma carga de valores negativos do passado procurando inculcar-lhes, com a incorporação de uma nova identidade, valores positivos que motivem "atitudes positivas" (HONNETH, 2009).

Acompanhando este processo de incorporação e positivação da agricultura familiar também ocorreu um debate semelhante nos fóruns da Contag. A substituição da categoria "pequena produção" pela de "agricultura familiar" foi tratado no II Congresso Extraordinário da Contag realizado em 1999. São registrados os motivos da substituição do termo:
O conceito "pequeno produtor" permitia que um de seus parâmetros fosse o tamanho da parcela de terra explorada. $\mathrm{O}$ de agricultor familiar carrega uma complexidade econômica, social e cultural muito maior. O objetivo agora não é simplesmente apoiar uma agricultura de subsistência ou de resistência na terra, mas sim de promover o desenvolvimento econômico do trabalhador e da trabalhadora (CONTAG, 1999, p. 41).

Nos Anais do VIII Congresso da Contag de 2001 voltou-se ao tema e fez-se a recomendação de que noção de agricultura familiar fosse incorporada oficialmente como linguagem pelo movimento sindical e pelos programas que este participa, substituído outros termos tais como: pequeno produtor e micro ou miniprodutores (CONTAG, 2001). Os diminutivos presentes nestas denominações incomodavam. Reduziam os agricultores e a sua importância, portanto, eram percebidas como inadequados. Mesmo que desde meados dos anos de 1990 estivesse sendo usada a expressão agricultura familiar pelo sindicalismo, esta convivia com outros termos e eram consideradas, muitas vezes, como sinônimos. Foi com o aprofundamento do debate sobre o projeto político do sindicalismo que a noção de agricultura familiar assumiu um significado diferente, positivo, considerado mais adequado.

Nos congressos seguintes é consolidado este novo sentido. No X Congresso de 2009 afirma-se que o campo não pode ser visto somente como a "propriedade", a "produtividade", as "relações com mercado". Ao contrário disso, o "campo brasileiro, em especial agricultura familiar, tem que ser local de alegria, prazer e atratividade, para que as famílias aí existentes, em especial, os jovens permaneçam e gostem deste espaço" (CONTAG, 2009, p. 41). Nesse sentido, a família agricultora não pode ser vista somente como uma "unidade de produção" ou como um "estabelecimento agrícola" onde somente os produtos da agricultura são valorizados quando entregues ao mercado. Para chegar nesse entendimento, um passo importante foi dado com a incorporação da noção de agricultura familiar que reconhece 
vários sujeitos no espaço rural. Sobre este tema alguns depoimentos de dirigentes sindicais do Sulsão ilustrativos:

Agricultura familiar é pai, é mãe, é filho, é filha, é genro, é o grupo familiar que tá naquela agricultura, naquela pequena propriedade. [...] A pequena propriedade, nós era quinta roda da carroça, nós éramos o lixo, nós não aparecia em lugar nenhum. A partir daí as coisas começaram a crescer, nós começamos a reivindicar (Heitor Schuch, ex-presidente da Fetag-RS, entrevista ao autor, 2010).

Se tu vai dizer "pequeno agricultor" parece que tá dizendo que é só o homem, lá "pequeno agricultor". Então a "agricultura familiar" quer dizer que envolve homem, mulher e jovem. Então é uma agricultura familiar onde todo mundo faz parte. É essa a visão que nós tivemos no momento de dar o nome da "agricultura familiar", é quando toda a família participa do processo né, no processo da agricultura, no seu planejamento (Dilva Brum, Coletivo de Mulheres da Fetraf-Sul, entrevista ao autor, 2010).

Pelos depoimentos, fica evidente uma percepção de que a noção de agricultura familiar reconhece os diferentes sujeitos presentes na agricultura (homens, mulheres, jovens, idosos) e está associada ao "grupo familiar" que vive e trabalha na agricultura. Visando atender as especificidades e os diferentes interesses entre estes sujeitos tanto na Fetraf quanto na Contag atualmente existem coletivos ou secretarias de mulheres, de jovens e de idosos que promovem eventos, projetos e pautas de reivindicações específicas para esses públicos. Cada sujeito da agricultura familiar tem um espaço próprio nas estruturas sindicais.

Conjuntamente com perspectiva de valorização dos diferentes sujeitos sociais presentes na agricultura, o sindicalismo, nas suas duas vertentes, procura situar sua estratégia política de afirmação do modelo da agricultura familiar na ideia-força de que seriam os agricultores familiares os responsáveis por levar para a mesa dos brasileiros o seu alimento, procurando ressaltar frequentemente a sua importância socioeconômica no cenário nacional. Alguns estudos produzidos pela academia, pelo convênio FAO/Incra e pelo IBGE dão respaldo para esta tese (segundo o Censo Agropecuário de 2006, a agricultura familiar é responsável por cerca de $70 \%$ dos alimentos oferecidos aos mercado interno). Estes dados são apropriados pelas organizações sindicais na luta por recursos públicos e na luta simbólica por afirmação deste modelo de agricultura frente ao modelo do agronegócio, que estaria mais interessado na exportação de commodities do que abastecer o mercado interno.

Procurando se apropriar desta ideia-força, a Fetraf elaborou um lema que sintetiza muito bem esta ideia: Agricultura Familiar: as mãos que alimentam a nação (FETRAF-SUL, 2004). Trata-se da ideia de que seriam as mãos dos agricultores familiares que produzem os alimentos para a Nação, para o povo brasileiro, além de procurar evidenciar a sua importância econômica, carrega forte simbolismo uma vez que esse formato de agricultura é caracterizado pelo uso expressivo do trabalho manual nas atividades produtivas. Portanto, seria um trabalho artesanal, feito com todo cuidado, para ir à mesa das pessoas. ${ }^{14}$

Essa valorização do trabalho realizado pela família agricultura diretamente envolvida no processo produtivo também afirma um modelo de organização da produção que difere visceralmente de outro modelo em que ocorre a separação de atividades de gestão do trabalho: o modelo patronal. Este último modelo foi historicamente empregado no país pelas grandes fazendas onde o trabalho diretamente envolvido nas atividades produtivas (manual) era realizado primeiramente pelo escravo, depois pelo empregado ou o agregado, enquanto o patrão fazia o gerencia-

14. Essa valorização do trabalho manual, artesanal, ligado às formas tradicionais de produção também faz parte de um processo mais amplo de revalorização das formas de fazer e dos produtos da agricultura sadios, naturais e pouco processados. São produtos considerados típicos da região, com forte apelo à tradição e ao costume, em oposição aos produtos industrializados, considerados artificiais. Sobre este tema ver Dorigon e Renk (2011). 
mento (fazendo uso do intelecto, sem sujar as mãos). ${ }^{15}$ Neste modelo, que mantém alguns fios de continuidade com os do passado e até mesmo fortaleceu-se nos dias atuais, ocorre um acentuado desprestígio do trabalho manual, realizado por pessoas consideradas de baixa qualificação, que só podem executar funções braçais, de uso simples de força bruta. No modelo familiar, diferentemente, são valorizadas suas características de não separação entre quem pensa e quem executa as atividades. Existe uma relação íntima entre a gestão da exploração familiar e a execução de seu processo produtivo pelos membros da família. Portanto, neste modelo tende a ocorrer uma reversão do qualificativo negativo atribuído ao trabalho manual e aos sujeitos sociais que realizam tais trabalhos.

\section{Considerações finais}

Em três décadas a percepção sobre a agricultura familiar mudou significativamente no país. Se no final da década de 1970 e durante a de 1980 era considerada pela academia e pelo Estado como um setor social que estava em vias de desaparecimento (o seu fim era eminente), a partir de meados da década de 1990 a situação começa a se alterar, a agricultura familiar passou a ser alvo de política específicas do Estado, trabalhos acadêmicos e de órgãos do Estado passaram a valorizar este modelo de agricultura e as organizações sindicais no campo a assumiram como identidade política e como projeto de agricultura a ser construído no país.

A principal questão que se evidenciou neste texto foi que a construção da categoria agricultura familiar no Brasil, ao contrário do que querem fazer crer muitos, não é produto exclusivo dos trabalhos acadêmicos a que são atribuídos a primazia do uso do terno e nem, tão pouco, dos estudos de cooperação FAO/Incra e das políticas públicas (como o Pronaf), mas, sua construção no país foi

15. O modelo histórico de separação do trabalho manual do trabalho intelectual é analisado por Prado Jr. (1996). realizada por um conjunto de experiências, reflexões e iniciativas de diversos atores, aí incluídas as organizações sindicais. Se, de um lado, o debate acadêmico sobre a agricultura familiar e as elaborações do convênio FAO/Incra foram grandes impulsionadores de uma nova forma de olhar para os segmentos subalternos na agricultura e para a definição de políticas públicas para este público, de outro, a atuação das organizações sindicais e suas elaborações sobre a Lei Agrícola e o Projeto Alternativo de Desenvolvimento, juntamente com as pressões realizadas pelos Gritos da Terra Brasil por políticas públicas diferenciadas contribuíram para que os pesquisadores formassem os modelos teóricos e para pressionar o Estado a formular as políticas públicas. Esta circulação de informações e de categorias, essa complementaridade entre pesquisas acadêmicas, de agências estatais e internacionais e as ações de reivindicação e proposição do sindicalismo logrou colocar no centro das ações de desenvolvimento rural o agricultor familiar.

As duas organizações sindicais aqui tratadas (Contag e Fetraf) assumem o fortalecimento da agricultura familiar como centro de um projeto de desenvolvimento rural para país. Para elas, a agricultura familiar corresponde a um modelo de organização da agropecuária assentado em unidades familiares de produção, onde o grupo familiar, em geral, é proprietários dos meios de produção, planeja, gestiona e executa as atividades produtivas e a força de trabalho é predominantemente familiar. Este modelo é considerado mais vantajoso social, econômico e ambientalmente (por ser mais democrático, eficiente e sustentável) quando compara com o modelo de exploração patronal.

As organizações sindicais procuram construir "atitudes positivas" (HONNETH, 2009) ao assumirem a agricultura familiar como identidade política. No processo de incorporação desta identidade ocorreu uma tentativa de superar uma condição de inferioridade social atribuída aos pequenos produtores, reabilitando-os social e politicamente como personagens do mundo contemporâneo e participantes ativos do desenvolvimento. Com esta mudança foram incorporados 
novos valores positivos, identificados com o novo lugar que se pretende para este grupo de agricultores. Nesse sentido, é construída a ideia-força de que são os agricultores familiares os grandes produtores de alimentos para os brasileiros.

Por fim, cabe destacar que este direcionamento do reconhecimento da agricultura familiar para os aspectos produtivos e de integração aos mercados de alimentos também traz contradições para as organizações sindicais e as suas bases. Tem gerado certos atritos com organizações aliadas, como as da Via Campesina (especialmente MST e MPA), que têm atuado na construção de projetos de maior autonomia dos agricultores (chamados por estas de camponeses) e com outros grupos subalternos do campo, tais como: indígenas, quilombolas, extrativistas, ribeirinhos, etc. Muitos destes fazem parte das bases sindicais ou foram aliados em diversos momentos na luta contra os latifundiários ou os agentes do agronegócio, adversários comuns, mas não aderem ao modelo de agricultura familiar "colona", centrado na produção para os mercados e na propriedade familiar. Estes grupos têm formado atores políticos próprios e ensaiado rupturas com o sindicalismo e o modelo da agricultura familiar.

\section{Referências bibliográficas}

ABRAMOVAY, R. Paradigmas do capitalismo agrário em questão. 2 ed. Campinas: Hucitec, 1998.

BONATO, A. A. O DESER na história das organizações da agricultura familiar da região Sul. DESER 15 anos, ago. 2003.

BOURDIEU, P. O poder simbólico. 10. ed. Rio de Janeiro: Bertrand Brasil, 2005.

BRUMER, A. et al. A exploração familiar no Brasil. In: LAMARCHE, H. A agricultura familiar: comparação internacional. Campinas: Editora da Unicamp, 1993.

CASTILHOS, D. de. A construção da identidade da agricultura familiar. Curitiba, 1999.

CONTAG. Anais do I Congresso Nacional Extraordinário dos Trabalhadores Rurais. 1994.

Anais do VII Congresso Nacional dos Trabalhadores Rurais. 1998.
. Anais do II Congresso Nacional Extraordinário dos Trabalhadores Rurais. 1999.

Anais do VIII Congresso Nacional dos Trabalhadores Rurais. 2001.

Anais do $X$ Congresso Nacional dos Trabalhadores e Trabalhadoras Rurais. 2009.

DELGADO, G. Agricultura familiar e política agrícola no Brasil: situação atual e perspectivas. Revista da Associação Brasileira de Reforma Agrária, v. 24, n. 3, set./ dez, 1994.

. et al. Estratégias agroindustriais e grupos sociais rurais: o caso do MERCOSUL. Rio de Janeiro: Forense, UFRRJ, 1996.

DNTR. Caderno de tese do II Congresso do Departamento Nacional dos Trabalhadores Rurais. Goiânia, 1993.

DORIGON, C. e RENK, A. Técnicas e métodos tradicionais de processamento de produtos coloniais: de "miudezas de colonos pobres" aos mercados de qualidade diferenciada. Rev. de Economia Agrícola, v. 58, n. 1, 2011.

FAO/INCRA. Diretrizes de política agráriae desenvolvimento sustentável. Brasília, 1994 (Versão resumida do Relatório Final do Projeto UTF/BRA/036).

FAVARETO, A. Paradigmas do desenvolvimento rural em questão. São Paulo: Iglu/Fapesp, 2007.

FAVARETO, A. S. Agricultores, trabalhadores: os trinta anos do novo sindicalismo rural no Brasil. Revista brasileira de ciências sociais, v. 21, n. 62, out. 2006.

FERNANDES, B. M. Disputas territoriales entre el campesinado y la agroindustria en Brasil. Cuadernos del CENDES, a. 29, n. 81, 2012.

FETRAF-SUL. Resoluções do I Congresso da FETRAFSul/CUT. Chapecó, 2004.

GOLDIN, A. Corporativismo, neocorporativismo y libertad sindical. Derecho Laboral, v. LV, n. 247, 2013.

GRAMSCI, A. Cadernos do cárcere. Rio de Janeiro: Civilização Brasileira, 2002 (v. 5).

GRAZIANO DA SILVA, J. (Coord.) Estrutura agrária e produção de subsistência na agricultura brasileira. São Paulo: Hucitec, 1978.

GRISA, C. e WESZ JR., V. Políticas públicas para a agricultura familiar: entre avanços e desafios. Carta Maior, 25 set. 2010.

HONNETH, A. Luta por reconhecimento: a gramática moral dos conflitos sociais. 2. ed. São Paulo: Editora 34, 2009. 
IBGE. Censo Agropecuário 2006 - Agricultura Familiar: primeiros resultados - Brasil, grandes regiões e unidades da federação. Rio de Janeiro: IBGE, 2009.

KAGEYAMA, Â. e BERGAMASCO, S. M. P. Novos dados sobre a produção familiar no campo. XXVII Congresso da SOBER.Piracicaba, 1989.

LAMARCHE, H. (Coord.). A agricultura familiar: comparação internacional - Uma realidade multiforme. Campinas: Editora da Unicamp, 1993 (v.I).

(Coord.). A agricultura familiar: comparação internacional: do mito à realidade. Campinas: Editora da Unicamp, 1998 (v. II).

LEITE, S. et al. Avaliando a gestão das políticas agrícolas no Brasil: uma ênfase no papel dos policymakers. Rio de Janeiro: CPDA, 2007 (Convênio CPDA-NEAD3.

MAARA/CONTAG. Propostas e recomendações de política agrícola diferenciada para o pequeno produtor. Brasília, 1994 (Relatório da Comissão Técnica MAARA/ CONTAG, Portarias MAARA 692, de 30/11/93 e 42, de 24/01/94).

MEDEIROS, L. S. História dos movimentos sociais no campo.Rio de Janeiro: FASE, 1989.

Lavradores, trabalhadores agrícolas, camponeses: os comunistas e a constituição de classes no campo. Tese (Doutorado), Programa de Pós-graduação em Ciências Sociais, UNICAMP, Campinas, 1995.

Sem terra, assentados, agricultores familiares: considerações sobre os conflitos sociais e as formas de organização dos trabalhadores rurais brasileiros. In: GIARRACCA, N. (Org.). ¿Una nueva ruralidad en América Latina? Buenos Aires: CLACSO, 2001.

MOTTA, M. e ZARTH, P. Formas de resistência camponesa: visibilidade e diversidade de conflitos ao longo da história. São Paulo: Ed. Unesp, 2008.

NOVAES, R. R. Dissolver a neblina. Teoria $\mathcal{E}$ debate, n. 08 , out./dez. 1989.

De corpo e alma: catolicismo, classes sociais e conflitos no campo. Rio de Janeiro: Ed. Graphia, 1997.
OFFE, C. Atribuição de status público aos grupos de interesse. In: OFFE, C. Capitalismo desorganizado. São Paulo: Brasilienses, 1989.

PALMEIRA, M. A diversidade da luta no campo: luta camponesa e diferenciação do campesinato. In: PAIVA, V. (Org.). Igreja e questão agrária. São Paulo: Loyola, 1985.

PICOLOTTO, E. L. As mãos que alimentam a nação: agricultura familiar, sindicalismo e política. Tese (Doutorado), Programa de Pós-graduação de Ciências Sociais em Desenvolvimento, Agricultura e Sociedade, UFRRJ, 2011.

. A formação de um sindicalismo de agricultores familiares no Sul do Brasil. Sociologias, v. 16, n. 35, 2014.

PRADO JR, C. Formação do Brasil contemporâneo. 23. ed. São Paulo: Brasiliense, 1996.

QUEIROZ, M. I. P. Uma categoria rural esquecida. In: WELCH, C. et al. (Org.). Camponeses brasileiros: leituras e interpretações clássicas. São Paulo: Ed. UNESP, 2009.

ROMANO, J. O. Atores e processos sociais agrários no MERCOSUL, Estudos Sociedade e Agricultura, n. 6, jul. 1996.

SABOURIN, E. Origens, evolução e institucionalização da política de agricultura familiar no Brasil. Seminário Nacional Agricultura Familiar Brasileira: desafios atuais e perspectivas de Futuro. Brasília, 2014.

TAVARES DOS SANTOS, J. V. Matuchos: exclusão e luta. Petrópolis: Vozes, 1993.

THOMPSON, E. P. A formação da classe operária inglesa. Rio de Janeiro: Paz e Terra, 1987.

VEIGA, J. E. Desenvolvimento agrícola: uma visão histórica. São Paulo: Hucitec, 1991.

VENCESLAU, P. T. Limpar o terreno. Teoria $\mathcal{E}$ debate, n. 6, abr./jun. 1989.

WANDERLEY, M. N. B. Raízes históricas do campesinato brasileiro. XX Encontro Anual da ANPOCS. Caxambu, 1996.

O mundo rural como espaço de vida: reflexões sobre a propriedade da terra, agricultura familiar e ruralidade.Porto Alegre: Ed. UFRGS, 2009. 
